\title{
GEOMORPHIC CONSTRAINS ON THE EVOLUTION OF THE AGGITIS RIVER BASIN NORTHERN GREECE (A PRELIMINARY REPORT)
}

\author{
Pennos Ch. ${ }^{1}$, Lauritzen S.-E. ${ }^{1}$, Pechlivanidou S. ${ }^{1}$ and Sotiriadis Y. ${ }^{2}$ \\ ${ }^{1}$ University of Bergen, Department of Earth Science, 5020-N, Bergen, Norway, \\ christos.pennos@uib.no,stein.lauritzen@uib.no,sofia.pechlivanidou@uib.no \\ ${ }^{2}$ Technological Institute of Eastern Macedonia and Thrace, Department of Electrical Engineering, \\ 65403-GR, Kavala, Greece, gesodir@teiemt.gr
}

\begin{abstract}
In this paper we discuss the landscape evolution of the Aggitis River basin by correlating the morphological characteristics of the Maaras Cave (Aggitis River spring) with the main geomorphological features of the Aggitis fluvial valley. We combine the various morphological features that are hidden inside the Maaras Cave with the surface geomorphology of the river valley in order to trace the imprint of the different evolutionary stages on the landscape. Also, we provide a relative chronological framework for the evolution of the area. The 3D survey of the Maaras Cave shows that the roof of the cave is looping-like shaped in contrast to the floor of the cave that shows low slopes and holds thick clastic sediment deposits. Furthermore, the geomorphological mapping of the Aggitis River valley shows two prominent windgaps at the southern part of the basin that formed as the result of river capture. Our results suggest that the Aggitis River basin suffered four major evolutionary stages from the Neogene until the Quaternary.
\end{abstract}

Key words: Landscape evolution, Maaras Cave, Cave morphology.

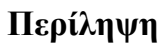

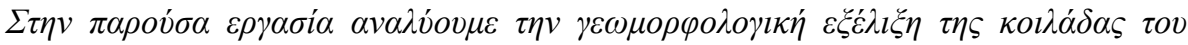

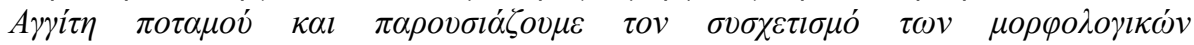

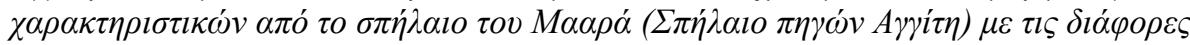

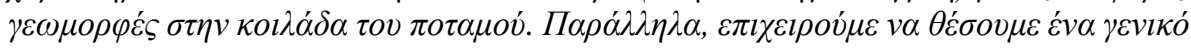

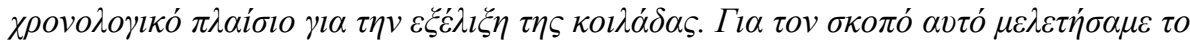

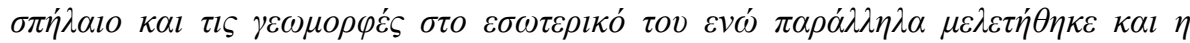

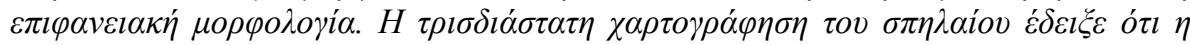

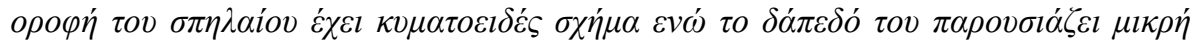

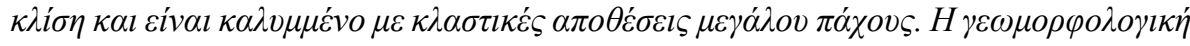

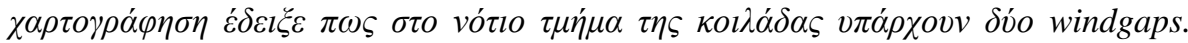

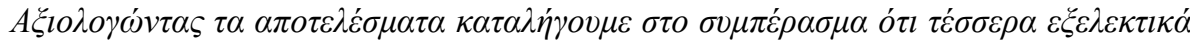

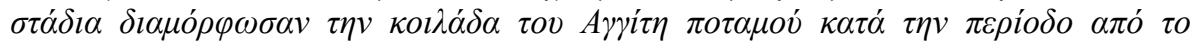

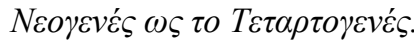

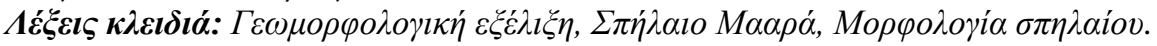




\section{Introduction}

Landscape is the result of processes that generate and destroy topographic relief (D'Arcy and Whittaker, 2014). Topography is gradually, over geologic time, build-up by tectonic forces like uplift, subsidence and crustal deformation (e.g. Whipple, 2004; Allen, 2008; Whittaker and Boulton, 2012) where at the same time erosion is modifying its characteristics (e.g. DiBiase and Whipple, 2011 and references within). This interplay between endogenic and exogenic processes is best recorded in various fluvial systems. The surficial drainage network is often studied in order to extract information on landscape evolution (e.g. Dadson et al., 2003; Bishop, 2007; Allen, 2008; Cyr et al., 2010). In areas where karst caves occur within fluvial landscapes one can extract additional information by studying these solutional landforms. Caves are forming under certain geologic conditions and therefore the various speleogenetic facies are driven by the geologic constrains. The imprint of these phases is the various morphological features that are evident on cave speleogens (Lauritzen and Lundberg, 2000).

Here, we discuss the landscape evolution of the Aggitis River basin by presenting a correlation of the morphological characteristics of the Maaras Cave (Aggitis river spring) with the geomorphological features of the fluvial valley of Aggitis. We further provide a relative chronology of the different evolutionary stages of the area. The main objective of this study is to couple recently acquired speleological and geomorphological data and to suggest a conceptual model for the topographic evolution of the Aggitis River basin. Our correlation enables further understanding of the drainage evolution in Northern Greece and their response on the post-Neogene tectonic activity.

\section{Study area}

\subsection{General}

The Aggitis river basin is located at the prefecture of eastern Macedonia in Northern Greece (Fig. 1). The mountain Menikio at the west, mountain Falakro at the east and from the Ori Lekanis and Paggeo Mountains at the southeast and southwest borders the basin, respectively. The river is formed by the discharge of an extensive underground system that passes through the Maaras Cave (Aggitis river springs). The input of this massive karstic system is located near the Ohiro village (Fig. 1) (Marinos et al., 1989; Xydakis, 1994; Reile, 2005). The known extent of the underground river is almost $12 \mathrm{~km}$, based on the results of the caving expedition that was held at 2010 by the French Federation of Speleology (Pascal Reile, head of the expedition) (Reile, pers. com).

\subsection{Geological setting}

The basin is a well-defined graben controlled by NW - SE normal faults that formed during the Neogene (Vavliakis et al., 1986; Psilovikos, 1990). The mountainous areas that border the basin are mostly dominated by metamorphic rocks (marble, gneiss and schists) and are intersected by small plutonic intrusions. The western part is covered by lacustrine clastic sediments deposited due to sea level rise during the Miocene (Papaphilippou-Pennou, 2004). Moreover, alluvial sediments cover the central part of the basin. At the area near the Philippi village, a large peat deposit occurs (Fig. 1). The Philippi fen is considered to be the thickest deposit of this type in the world with a thickness of almost $190 \mathrm{~m}$ (Kalaitzidis and Christanis, 2003). Finally, the deltaic deposits of the XiropotamosDoxato stream cover the southeast part of the lowland of the Aggitis basin (Gakis, 2002).

The Aggitis drainage network is highly influenced by the tectonic pattern of the basin (Vouvalidis et al., 2002; Pennos, 2009; Pennos et al., 2011). Different capturing events are evident throughout the valley, mainly driven from the tectonic processes that dominate the broader area (Pennos, 2009). The most pronounced of these events is near the village of Simvoli, where the Aggitis River is forced to make an almost 90 degrees" westward turn and to pass through the "Stena Petras" canyon. Former 
studies concerning this capturing event have suggested different theories about the opening of the canyon (Vavliakis et al., 1986; Astaras, 1987/1988).

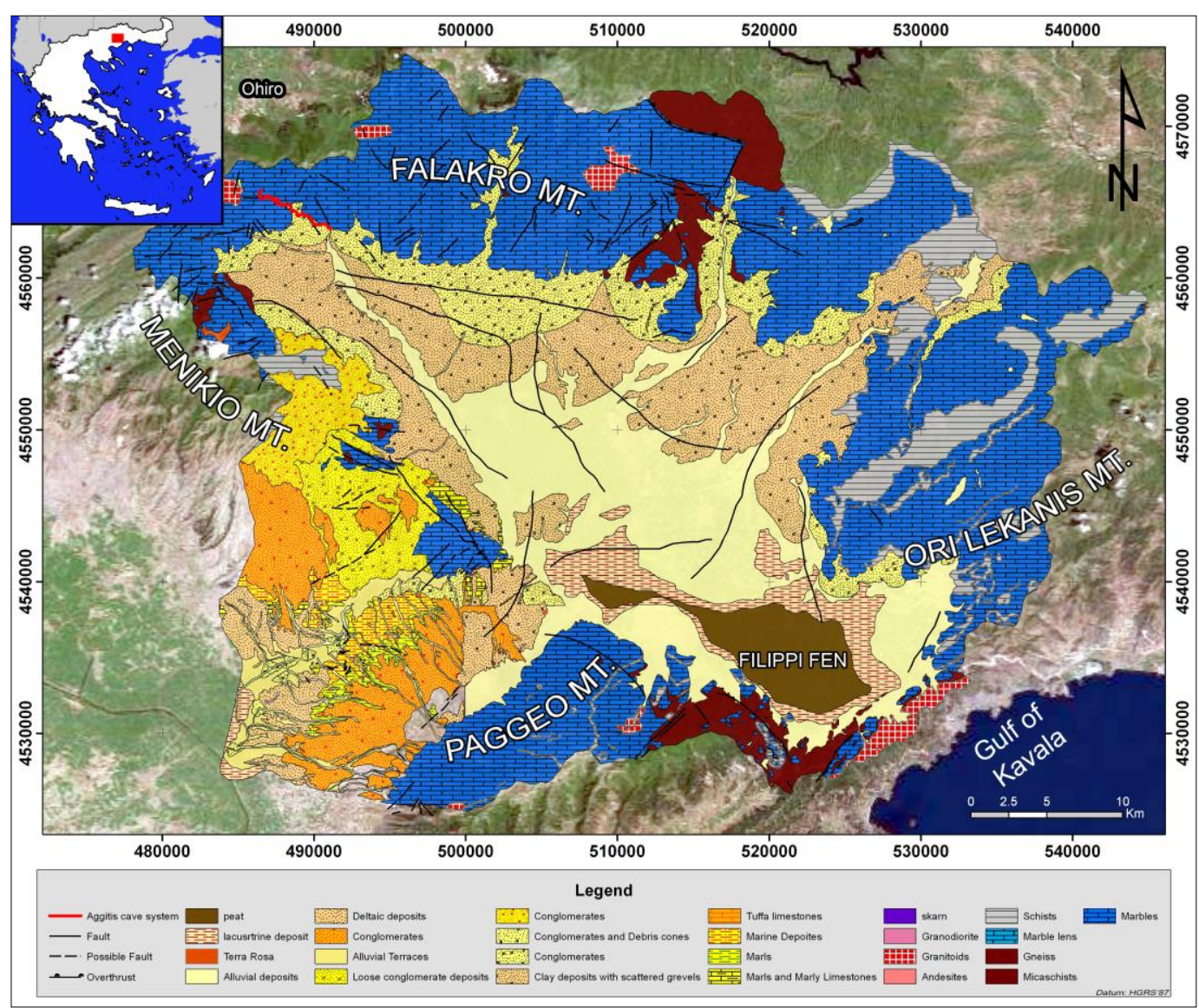

Figure 1 - Geological map of the Aggitis river basin. Based on Pennos (2009) and references within.

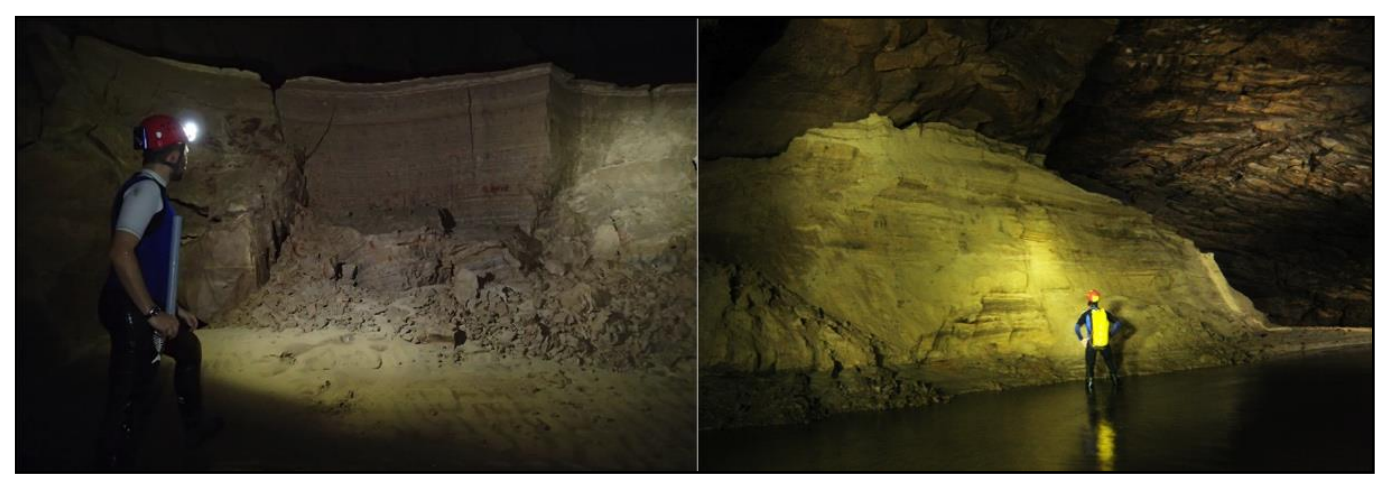

Figure 2 - Sediment terraces inside Maaras Cave.

\section{Methods}

In order to understand the controls on the evolution of the Aggitis River basin, we followed a twopart methodological approach. First, we focus on the meso- and macro-morphology of the Maaras 
Cave. The study of these speleogens provides the basis for understanding the geological conditions under which Maaras cave evolved through time. To this end we study the development of the main morphological features of the cave as response to base level changes of the Aggitis River valley. Additionally, we conducted a detailed geomorphological mapping of the area to understand the context under which these base level changes took place. This approach reveals the origin of the landforms and provides insights on the different evolutionary stages of the Aggitis basin.

\subsection{Underground mapping}

The most crucial part for the cave study was the creation of a detailed cave map. In order to acquire a detailed 3D survey, we followed the approach of a centerline with cross-sections vertical to the direction of the survey. In this way the dimensions and the shape of the cave passages are well descripted. All the measurements were completed using a laser-distance meter DistoA3 from Leica Geosystems, modified with the DistoX board that adds a three-axis compass, clinometer and Bluetooth connection (http://paperless.bheeb.ch/). The instrument connected via Bluetooth to a handheld device running the Pocketopo software on Windows Mobile OS where the measurements are transferred in real time and stored. Calibration of the instrument was also performed using the Pocketopo software (http://paperless.bheeb.ch/). In order to measure the macro-morphological characteristics of the Maaras Cave, the acquired data were imported to Therion (http://therion.speleo.sk/) and ArcGIS software. Finally, using the cave survey as a background we have mapped the sediment deposits and the mesoforms of the cave.

\subsection{Surface mapping}

We performed detailed geomorphological mapping of the Aggitis River basin that enabled us to depict the most prominent geomorphic characteristics of the area. Our mapping was based on the previous work of Pennos (2009) and field data, as well as on the use of digital elevation models acquired by the EU - DEM dataset (http://www.eea.europa.eu/data-and-maps/data/eu-dem). Our data sets were analysed using ArcGIS software to produce thematic maps that show the main geomorphological features of the Aggitis River basin.

\section{Results}

\subsection{Cave morphology}

Figure 3a shows a plan view of the Maaras Cave. The total length that we mapped together with the data acquired from the north branch of the cave (Theodosiadis, pers. com) is $10441 \mathrm{~m}$. The total altitudinal difference from the innermost part of the cave until the water exit (springs) is $71 \mathrm{~m}$ (Fig. $3 b)$. The slope of the river varies from $3 \%$ to $67 \%$. The highest slope occurs at the first part of the cave (Fig. 3c). The roof of the cave is following a looping pattern and the height varies from few centimetres up to $60 \mathrm{~m}$. In contrast, the cave floor is flat and covered with sandy clastic sediments (Fig. 3d). The sediments that cover the floor of the cave have a minimum thickness of $10 \mathrm{~m}$ (Marinos et al., 1989) at least at the first $2.5 \mathrm{~km}$ from the cave entrance. At the innermost parts of the cave, sediment terraces occur alongside the riverbed. The height of these terraces is gradually getting higher in relation to their distance from the entrance (Fig. 2). 


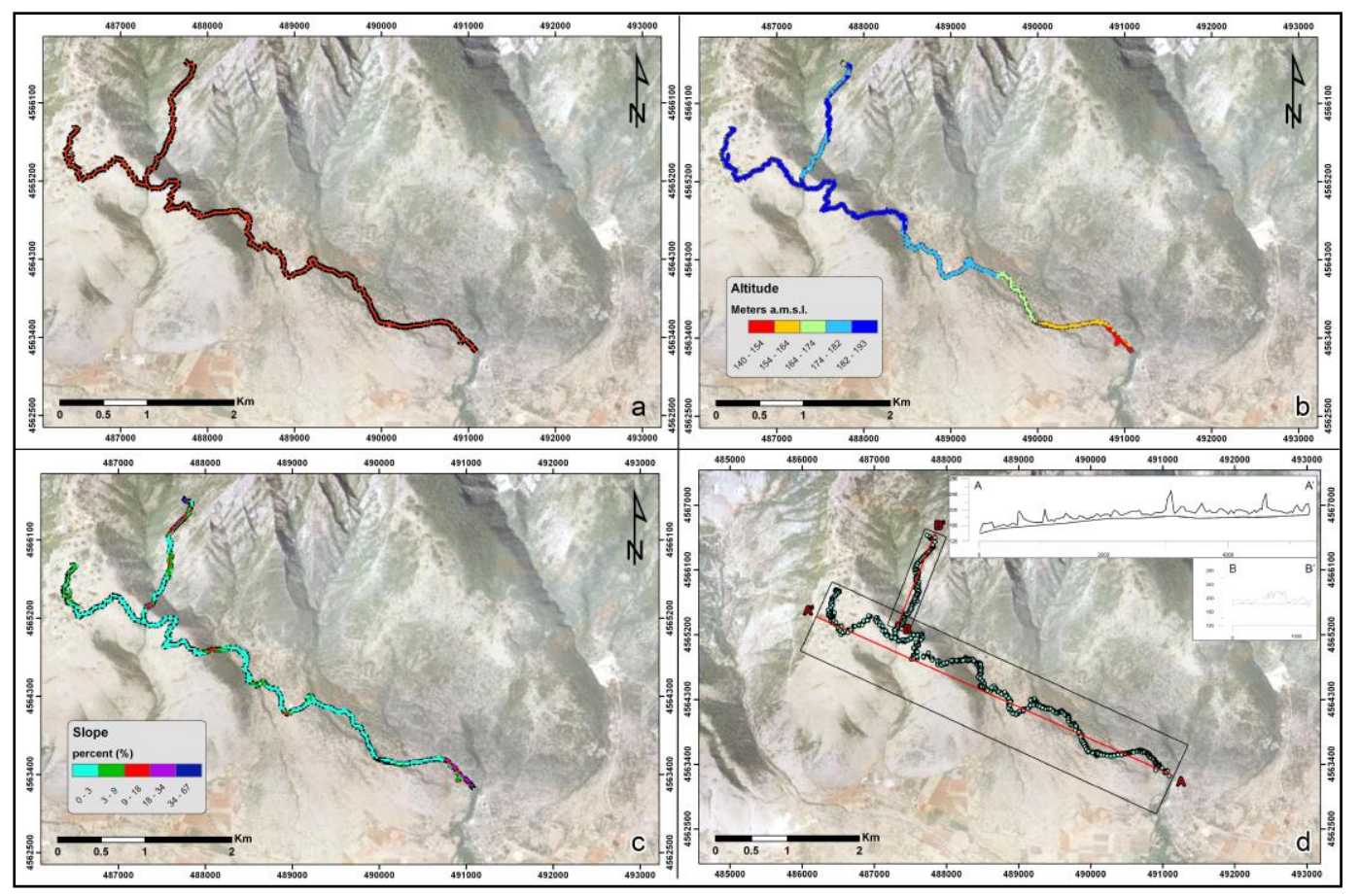

Figure 3 - a) Plan view of the cave survey interpolated on aerial picture from Ktimatologio.gr b) Cave floor altitude. c) Slope map of the cave floor. d) Longitudinal profiles of the cave roof and cave floor.

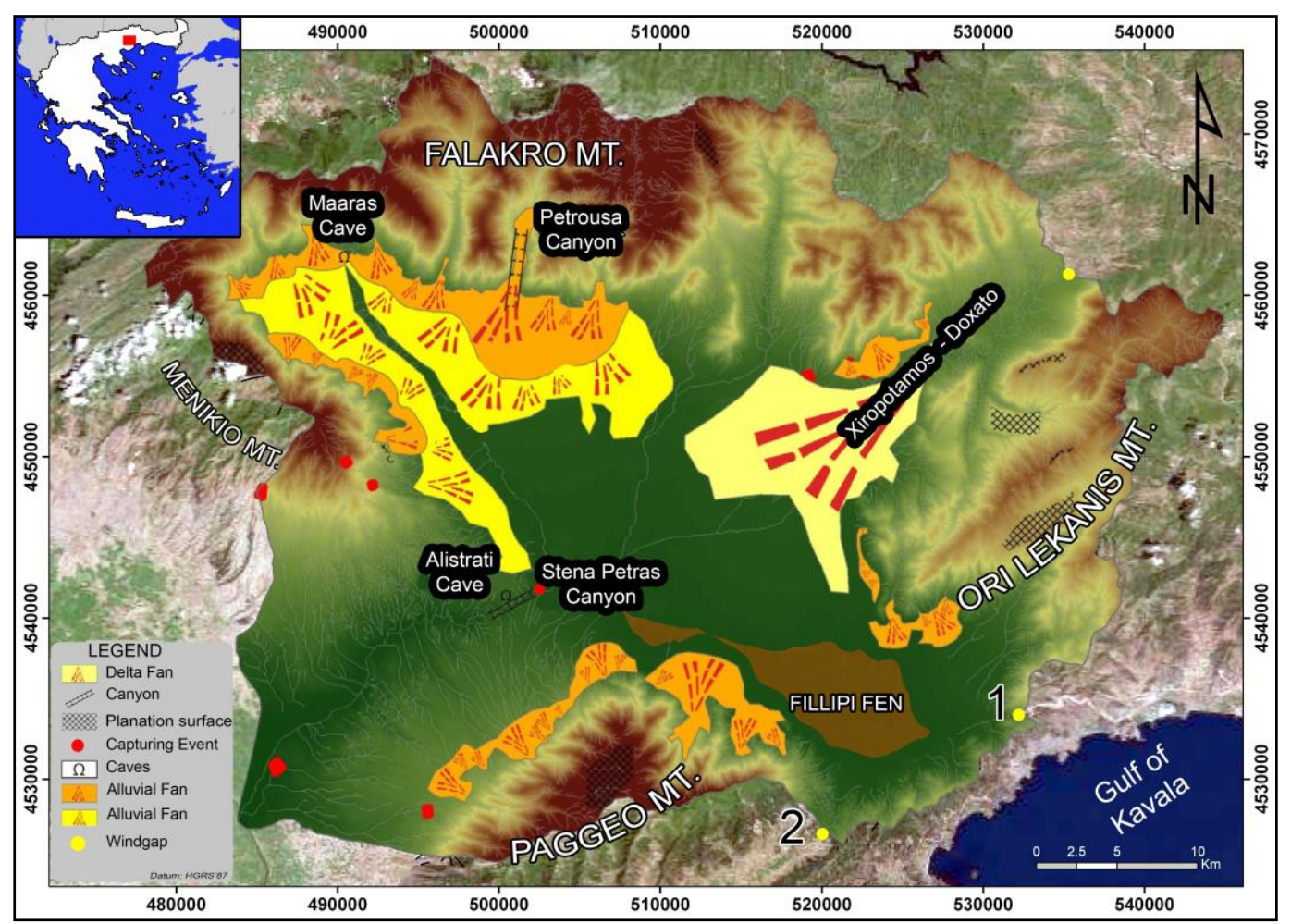

Figure 4 - Geomorphological map of Aggitis River basin (modified after Pennos, 2009). 


\subsection{Geomorphological mapping}

Detailed geomorphological mapping of the Aggitis River basin revealed significant features that depict the dynamics of the landscape. The northern part of the basin is dominated by complex alluvial fans that divert Aggitis River from its original course, and subsequently incubate the river in its present position (Fig. 4). These alluvial deposits can be distinguished into two generations according to their age; the oldest formations occupy almost the middle part of the valley, while the younger ones are closer to the mountains. The deltaic deposits of the Xiropotamos - Doxato stream, cover the eastern lowland part of the Aggitis valley whereas the Filippi Fen is covering the southern part of the basin. Two prominent windgaps are identified (windgaps 1and 2, see Fig. 4) at the mountains of Ori Lekanis and Paggeo, respectively. The first one is lying at the area near the city of Kavala at an altitude of $200 \mathrm{~m}$ a.m.s.l. and the other one near the village of Eleftheroupoli at $175 \mathrm{~m}$ a.m.s.l. (Fig. 5). Moreover, different capturing events of the drainage network can be found scattered all over the Aggitis River basin. Furthermore, two canyons are formed; the Petrousa canyon in the northern part of the basin near the village of Petrousa which is $8-10 \mathrm{~m}$ deep and the Stena Petras canyon at the southwest part reaching the depth of almost $80 \mathrm{~m}$ (Fig. 5). Finally, various planation surfaces where identified across the basin (Fig. 4).

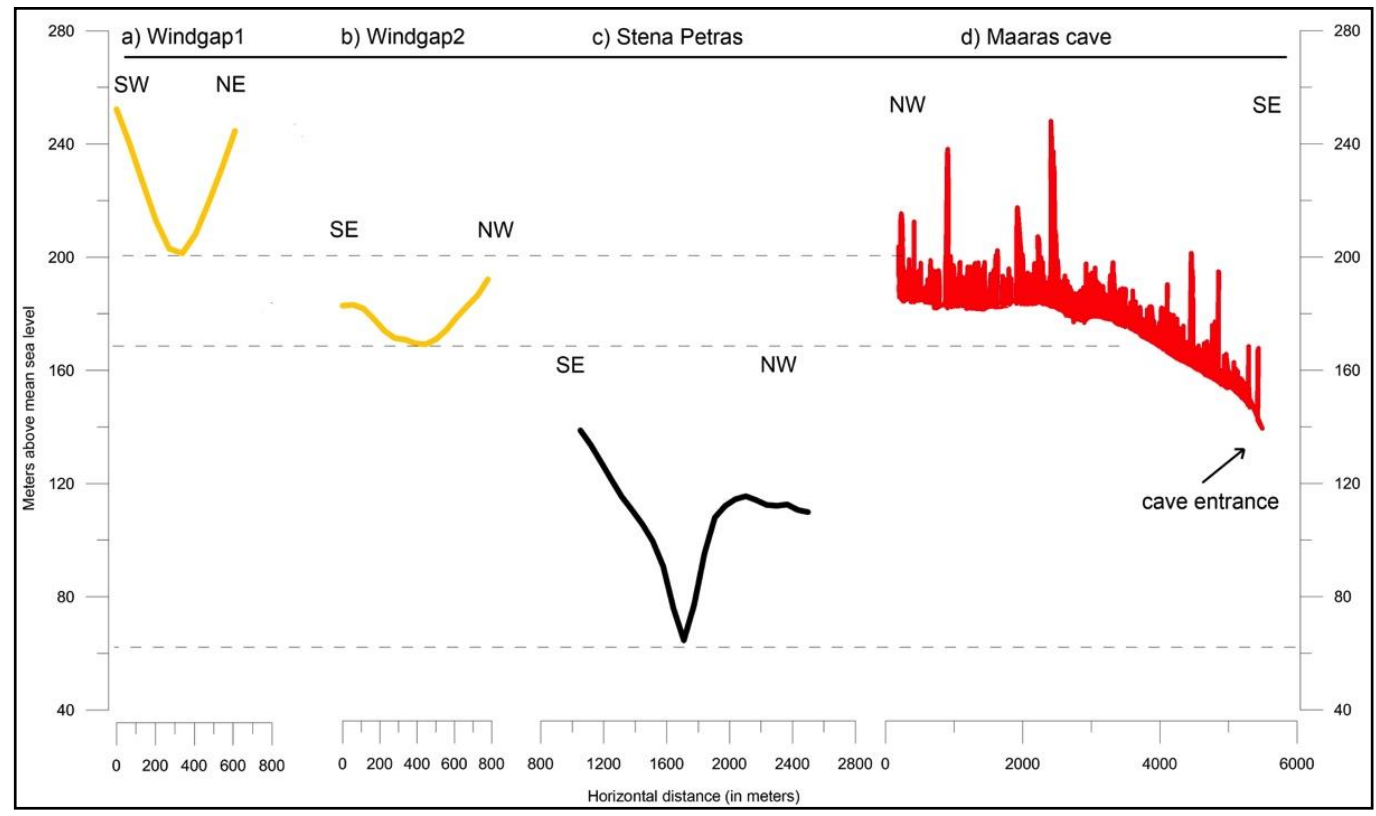

Figure 5 - Cross sections of windgaps 1 and 2 (a and b), of Stena Petras (c) and of Maaras Cave (d).

\section{Discussion}

In this section, we integrate the speleogenetic and morphological results to suggest a conceptual model for the landscape evolution of the Aggitis River basin. We present the different geomorphological evolutionary stages of the valley and their imprint on the Maaras Cave morphology.

During the initial evolutionary stage, the Aggitis River mouth was lying at the gulf of Kavala. At that time the river was flowing in an NNW - SSE direction passing through the area where the windgap 1 is found (for location see Fig. 4). According to Psilovikos (1990) this stage is dated back to Neogene. The karstic system at the northern part of the valley is already evolving; the cave is at 
that time a phreatic conduit below the water level, forming loops, that are evident now at the Maaras cave roof (Figs 3d and 5).

The second stage is characterized by the change in the Aggitis River course and the subsequent formation of windgap 1, as response to the uplift controlled by the core complex formation in the area of Kavala (Dinter and Royden, 1993; Dinter, 1998). The Aggitis River is shifting its flow by almost 90 degrees and it is exiting through the area where the windgap 2 is lying, near the Eletheroupoli village (for location see Fig. 4). At this stage, the Maaras Cave is likely lying below the water table.

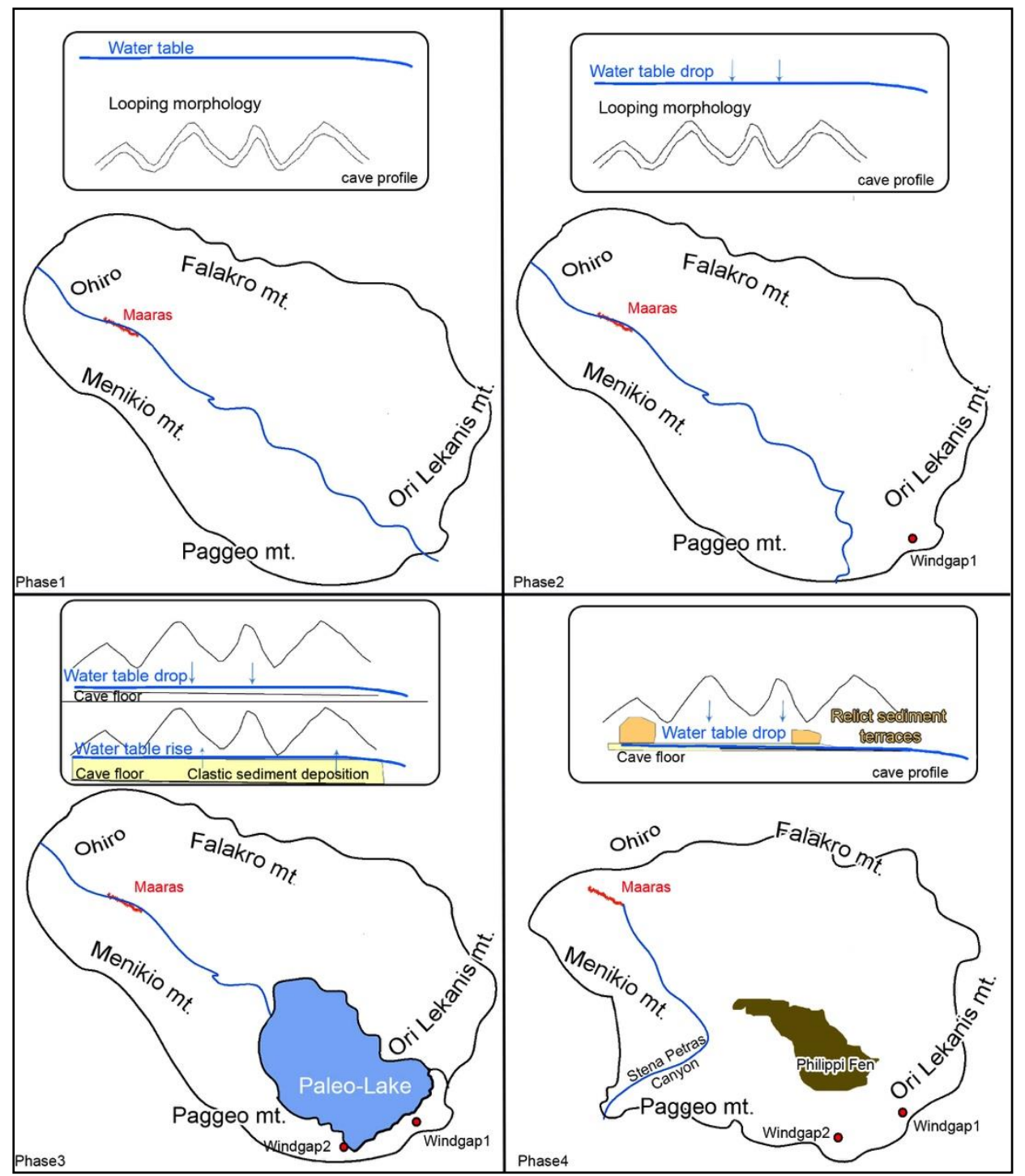

Figure 6 - Sketch of the conceptual evolutionary model of the Aggitis River Basin, note how the valley borders are changing in the last stage.

The continuous tectonic activity in the graben valley since the Neogene results in the deepening of the basin. At this stage the river cannot keep pace with the tectonic uplift and floods the lowest part of the valley to the south, since it cannot exit the valley towards the Aegean Sea. Thus, the windgap 2 forms at the Paggeo Mountain. An inner paleo-lake is formed that is evident by the Philippi Fen. 
Moreover, the flooding of the area enabled the deposition of fluvial sediments in the form of a deltaic sequence from the Xiropotamos - Doxato stream. Furthermore, the base level drop is also causing extended erosion inside the Maaras Cave. This erosional phase altered the morphology of the cave floor destroying the lower parts of the loops. Subsequently, the flooding of the southern part of the basin creates a local basel level rise, which favors the extensive deposition of clastic sediments inside the cave.

The final stage of the basin evolution is characterized by the formation of the "Stena Petras" gorge. According to Vavliakis et al. (1986) and Astaras (1987/1988) this event took place during late Quaternary. The formation of the gorge leads to the drainage of the inner paleo-lake and consequently to the lowering of the local base level. Inside the cave the erosional relict sediment terraces mark the drop at base level. Moreover, this drop is reflected by the increased slope at the first $2500 \mathrm{~m}$ inside the cave (see Fig. 5d). The cave floor will eventually adjust to a new equilibrium and it will reach a steady-state.

\section{Conclusions}

Our results are pointing out four major evolutionary stages of the Aggitis River basin. The imprint of these stages is evident both at the surficial and the cave geomorphology. The oldest stage is dated back to Neogene when the formation of the basin took place. Until the Quaternary the area experienced successive base level changes that altered significantly the drainage evolution as well as the Maaras Cave morphological pattern. These base level changes are mainly controlled by the evolution of the Aggitis graben valley. Dating data from the cave could provide a more robust chronological context.

\section{Acknowledgements}

We would like to thank the cavers Nikolaos Kortimanitsis, Eugenia Kiourexidou, Sverre Aksnes and Panagiotis Georgiou for their valuable help during the fieldwork inside the cave. Pascal Reille and Thomas Theodosiadis are highly acknowledged for the fruitful conversations and for introducing the cave to C.P. Ephorate of Paleoanthropology and Speleology of the Greek Ministry of Culture and the Municipality of Prosotsani are highly acknowledged for granting us access to work in the cave. Nikos Diafas and Dimitris Stergiakos, from the management authority of the cave, are thanked for helping us during our visits. We thank SPELEO club for providing us the diving data. An anonymous reviewer is acknowledged for the comments and remarks on the manuscript. C.P. was funded by the IKY-EEA grant under the theme "IKY scholarships, Integrated Management of Sea and Inland Waters" the theme is co-founded by the EEA grants - Financial Mechanism 2009$2014(85 \%)$ and the Hellenic General Secretariat for Investments and Development (15\%).

\section{References}

Allen, P.A., 2008. From landscapes into geological history, Nature, 451(7176), 274-276.

Astaras, T., 1987/1988. Underground karstic "selfpiracy" of the Aggitis River, passing through the "Stena Petras", near Alistrati, East Macedonia: Contribution on the evolution of the epigenetic valley of the Aggitis River (in Greek), Annales Geologiques de pays Helleniques, 33, 463-473.

Bishop, P., 2007. Long-term landscape evolution: linking tectonics and surface processes, Earth Surf. Proc. Land, 32(3), 329-365.

Cyr, A.J., Granger, D.E., Olivetti, V. and Molin, P., 2010. Quantifying rock uplift rates using channel steepness and cosmogenic nuclide-determined erosion rates: Examples from northern and southern Italy, Lithosphere, 2(3), 188-198.

D'Arcy, M. and Whittaker, A.C., 2014. Geomorphic constraints on landscape sensitivity to climate in tectonically active areas, Geomorphology, 204, 366-381. 
Dadson, S.J., Hovius, N., Chen, H., Dade, W.B., Hsieh, M.L., Willett, S.D., Hu, J.C., Horng, M.J., Chen, M.C., Stark, C.P., Lague, D. and Lin, J.C., 2003. Links between erosion, runoff variability and seismicity in the Taiwan orogen, Nature, 426(6967), 648-651.

DiBiase, R.A. and Whipple, K.X., 2011. The influence of erosion thresholds and runoff variability on the relationships among topography, climate, and erosion rate, Journal of Geophysical Research, 116(F4).

Dinter, D.A., 1998. Late Cenozoic extension of the Alpine collisional orogen, northeastern Greece: Origin of the north Aegean basin, Geological Society of America Bulletin, 110(9), 1208-1230.

Dinter, D.A., Royden, L., 1993. Late Cenozoic extension in northeastern Greece: Strymon Valley detachment system and Rhodope metamorphic core complex. Geology, 21(1), 45.

European Environment Agency, 2015. EU-DEM dataset, Digital Elevation Model over Europe (EUDEM). EEA, http://www.eea.europa.eu/data-and-maps/data/eu-dem.

Gakis, A., 2002. Gomorphological, sedimentological and enviromental evolution of the Xiropotamos - Doxato stream, Drama Basin. (in Greek), M.Sc. Thesis, Aristotle University of Thessaloniki, Thessaloniki.

Kalaitzidis, S. and Christanis, K., 2003. Scanning electron microscope studies of the Philippi peat (NE Greece): initial aspects, International Journal of Coal Geology, 54(1-2), 69-77.

Lauritzen, S.-E. and Lundberg, J., 2000. Solution and erosional morphology. In: Klimchouk, A., Ford, D.C., Palmer, A.N., eds., Speleogenesis: Evolution of Karst Aquifers, National Speleological Society, Huntsville, Ala., 407-426 pp.

Marinos, P., Xydakis, G., Dimadi, A. and Gounaris, T., 1989. The cave-spring Maaras, Drama (in Greek). In: Society, H.G., ed., 2nd Panhellenic Geographical Congrees, Athens.

Papaphilippou-Pennou, E., 2004. Dynamic evolution and recent exogenic processes of Strymon river network in Serres graben (North Greece), Ph.D. Thesis Aristotle University of Thessaloniki, Thessaloniki, $212 \mathrm{pp}$.

Pennos, C., 2009. Geomorphological study of the Aggitis river drainage basin, Drama, Macedonia, Greece (in Greek), M.Sc. Thesis, Aristotle University of Thessaloniki, Thessaloniki.

Pennos, C., Astaras, T., Vouvalidis, K., Papaphilippou-Pennou, E. and Pechlivanidou, S., 2011. Geomorphological and Morphotectonic features of the alluvial fans of the northern part of the Aggitis river basin (in Greek), Bulletin of the Geological Society of Greece, XLIV, 29-36.

Psilovikos, A., 1990. Neotectonic impact on the modification of drainage networks of the Southwestern Rhodope, Bulletin of the Geological Society of Greece, XXII, 171-182.

Reile, P., 2005. Le Karst du Massif du Falakro et la Résurgence de Maaras Résultats des travaux hydrogéologiques et Topographiques, 14th International congress of Speleology, Athens, Kalamos, Greece.

Vavliakis, E., Psilovikos, A. and Sotiriadis, L., 1986. The epigenetic Valley of the Aggitis river and its relation with the evolution of Drama and Serres basins, Geological and Geophysical studies (IGME), 6, 5-14.

Vouvalidis, K., Gakis, A., Vavliakis, E., Margoni, S., Mouzouri, G. and Psilovikos, A., 2002. Geomorphological observations in the hydrological basin of the Xeropotamos - Doxato river in Drama (Macedonia) (in Greek), 6th Pan-Hellenic Geographical Conference of the Hellenic Geographical Society, Hellenic Geographical Society, Thessaloniki, Greece.

Whipple, K.X., 2004. Bedrock Rivers and the Geomorphology of Active Orogens, Annual Review of Earth and Planetary Sciences, 32(1), 151-185.

Whittaker, A.C. and Boulton, S.J., 2012. Tectonic and climatic controls on knickpoint retreat rates and landscape response times, Journal of Geophysical Research, 117(F2).

Xydakis, G., 1994. Touristic Development of a Large Karstic Conduit. The Case of the Subterranean River and Cave of Piges Aggiti (Maara), Drama, N. Greece. (in Greek), Bulletin de la Societe Speleologique de Grece, XXI. 